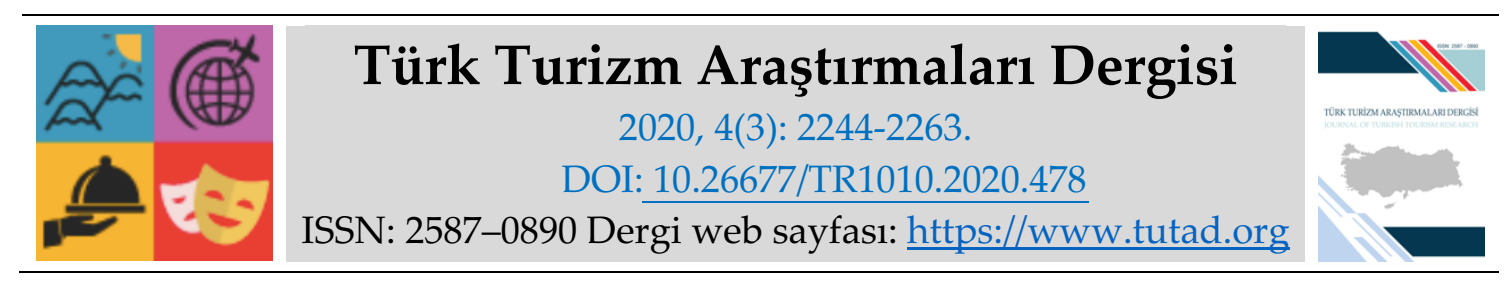

ARASTIRMA MAKALESI

\title{
Otel İşletmelerinde Dönüştürücü Liderliğin Rekabet Zekâsına Etkisinde Örgütsel Öğrenmenin Aracılık Rolü
}

Dr. Öğr. Üyesi Seda Kayapalı Yıldırım, Kafkas Üniversitesi, Sarıkamış Turizm Fakültesi, Kars, eposta: seda.yildirim@kafkas.edu.tr

ORCID: https://orcid.org/0000-0003-4438-2445

\section{Öz}

Sürdürülebilir rekabet üstünlüğünün sağlanması, işletmelerin çevreden doğru bilgiyi elde etmesi, yorumlaması, depolaması, paylaşması gibi faktörlere bağlıdır. Bu durum ise işletmeleri yöneten yöneticilerin liderlik biçimleriyle yakından ilişkilidir. Özellikle rekabetin şiddetli olduğu otel işletmelerinde örgütler hayatta kalabilmek için kendilerini sürekli geliştirmek ve çevresel şartlara uyum sağlamak zorundadır. Bu nedenle otel işletmeleri rakiplerinden bilgi ve istihbarat sağlamalı ve kendi içerisinde ürettiği bilgiyle rekabet üstünlüğü sağlayacak beceriyi oluşturmalıdır. Bu araştırmada dönüştürücü liderliğin rekabet zekâsına etkisinde örgütsel öğrenmenin aracılık rolünü incelemek amaçlanmıştır. Bu ana amaç doğrultusunda otellerde faaliyet gösteren 208 adet alt, orta ve üst düzey yöneticiye anket uygulanmış ve cevaplar analize tabi tutulmuştur. Yapısal Eşitlik Modellemesi analizlerinin sonuçlarına göre dönüştürücü liderliğin örgütsel öğrenmenin tüm alt boyutlarını ve rekabet zekâsını doğrudan anlamlı ve olumlu olarak etkilediği belirlenmiştir. Diğer yandan örgütsel öğrenmenin tüm alt boyutlarıyla rekabet zekâsını doğrudan olumlu olarak etkilediği tespit edilmiştir. Ayrıca dönüştürücü liderliğin rekabet zekasına etkisinde öğrenmeye bağlllık, paylaşılan vizyon ve açı görüşlülük aracı role sahiptir.

Anahtar Kelimeler: Dönüştürücü Liderlik, Öğrenmeye Bağlllık, Paylaşılan Vizyon, Açık Görüşlülük, Rekabet Zekâsı.

Makale Gönderme Tarihi: 27.03.2020

Makale Kabul Tarihi: 02.07.2020

\section{Önerilen Atıf:}

Kayapalı Yıldırım, S. (2020). Otel İşletmelerinde Dönüştürücü Liderliğin Rekabet Zekâsına Etkisinde Örgütsel Öğrenmenin Aracılık Rolü, Türk Turizm Araştırmaları Dergisi, 4(3): 2244-2263.

(C) 2020 Türk Turizm Araştırmaları Dergisi. 


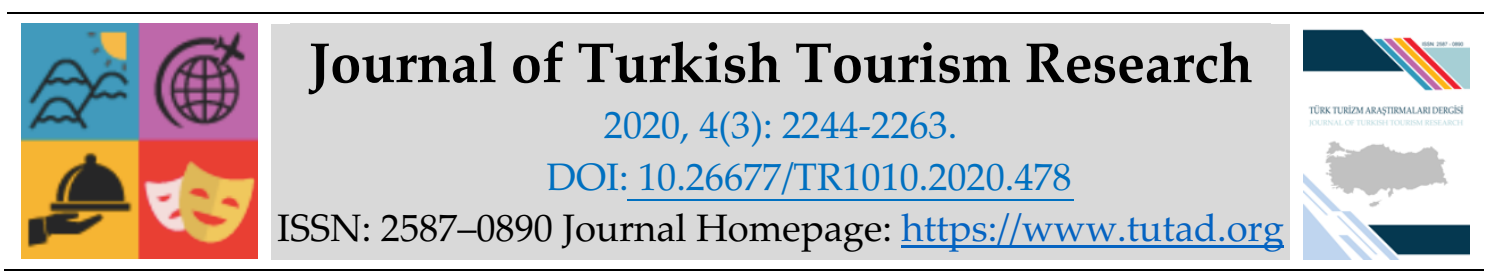

\title{
RESEARCH PAPER
}

\section{The Mediating Role of Organizational Learning on the Effects of Transformational Leadership on Competitive Intelligence in Hotels}

Assistant Prof. Dr. Seda KAYAPALI YILDIRIM, Kafkas University, Sarıkamış Faculty of Tourism, Kars, e-mail: seda.yildirim@kafkas.edu.tr ORCID: https://orcid.org/0000-0003-4438-2445

\begin{abstract}
Sustainable competitive advantage for organizations depends on factors including obtaining the right information from the environment, interpreting, storing, and sharing it. This is closely related to leadership styles of managers of these organizations. Particularly in hotels where competition is high, organizations need to improve themselves constantly and adapt to environmental conditions in order to survive. Therefore, hotel enterprises should obtain information from their competitors and master the skill that would provide a competitive advantage with the information produced inhouse. The purpose of this study is to evaluate the mediator role of organizational learning on the effects of transformational leadership on competitive intelligence. In alignment with this purpose, 208 managers at low, middle, and upper levels were surveyed and the data obtained were analyzed. The results of structural equation modeling analysis showed that transformational leadership impacts all dimensions of organizational learning and competitive intelligence positively. On the other hand, all dimensions of organizational learning impact competitive intelligence directly and positively. Additionally, a willingness to learn, possessing a shared vision, and open-mindedness have a mediator role in the effects of transformational leadership on competitive intelligence.
\end{abstract}

Keywords: Transformational Leadership, Commitment to Learning, Shared Vision, OpenMindedness, Competitive Intelligence.

Received: 27.03 .2020

Accepted: 02.07.2020

\section{Suggested Citation:}

Kayapalı Yıldırım, S. (2020). The Mediating Role of Organizational Learning on the Effects of Transformational Leadership on Competitive Intelligence in Hotels, Journal of Turkish Tourism Research, 4(3): 2244-2263.

(c) 2020 Türk Turizm Araştırmaları Dergisi. 


\section{Gíriş}

Teknolojide gerçekleşen hızlı değişim bütün çevresel unsurları sürekli değiştirmekte ve mevcut dinamizmin öncülügünde bilgi, örgütler için en önemli stratejik silahlardan biri olmaktadır. Üstelik örgütlerin öz yeteneklerinin değerli olmasını sağlayan bilgi, çabucak eskimekte ve rakipler tarafından kolayca taklit edilebilmektedir. Özellikle otel işletmeleri gibi hizmet üreten ve rekabetin şiddetli olduğu endüstrilerde bu durum daha da karmaşık bir hal almıştır. Hayatta kalabilmek için öz yeteneklerini geliştirmek isteyen otel işletmeleri için diğer çevresel unsurlardan elde edilen bilginin yanında rakiplerin birbirlerinden sağladığı istihbarat ile belli bir öğrenme düzeyine kavuşmak istekleri kendini açıkça göstermektedir. Bu noktada ise hem istihbarat bakış açısını hem de zeki örgütler bakış açısını karşılayan "rekabet zekâsı" kavramı ortaya çıkmaktadır. Rekabet zekâsı, uluslararası literatürde stratejik açıdan uzun yıllardır ele alınan bir kavramdır. Buna karşın ulusal literatür incelendiğinde kavramın rekabet zekâsı ve rekabet istihbaratı olarak iki ayrı kelime açısından az çalışma ile ele alındığı görülmektedir. Özellikle turizm sektöründe ve otel işletmelerinde bu konuyla ilgili yapılan çalışma yok denilecek kadar azdır. Bu nedenle Türkiye'de faaliyet gösteren oteller üzerinde rekabet zekâsı kavramıyla ilgili çalışmalar yapmak bilimsel literatüre katkı sunacaktır.

Rekabet zekâsı oluştururken bilginin, çevreden doğru bir şekilde sağlanması ve elde edilen bilginin depolanma biçimi ayrıca örgüt üyeleriyle zamanında paylaşılması önemli olan bir diğer husustur. Burada ise örgütün çeşitli tecrübeler neticesinde bir bakış açısı ve anlayış elde etme kabiliyeti kazanması ayrıca gözlem, deney veya analizler sonucu çevreden edindiği verilere dayalı olarak yapmış olduğu hataları ve elde ettiği başarıları değerlendirme istekliliği olarak tanımlanan (Mcgill, Slocum ve Leı, 1992:6) örgütsel öğrenme, kavramı ortaya çıkmaktadır. Çevreden elde edilen tüm bilgileri tecrübelerine yansıtan ve davranış biçimini buna göre değiştiren öğrenen örgütlerin, özellikle istihbarat bilgisiyle gelişen rekabet zekâsını ne düzeyde etkilediğini ortaya koymak araştırmanın amaçlarından birisini oluşturmaktadır.

Söz konusu değişkenler dışında otel işletmelerinin stratejik planlarını oluşturan yöneticilerin liderlik becerilerini ve özelliklerini ortaya koymak önemlidir. Günümüzün modern işletmelerinde örgütsel amaçları takipçilerin motivasyonlarını önemseyerek gerçekleştirmeye çalışan (Scandura ve Williams, 2004) dönüştürücü liderler, örgüte rekabet gücü kazandıran yetenek ve becerileri önemser ve geliştirmek için faaliyette bulunurlar (Bass, 1990). Bu nedenle uluslararası literatürde kabul görmüş en önemli liderlik biçimlerinden birisi olan dönüştürücü liderliğin bağımsız bir değişken olarak rekabet zekâsını nasıl etkilediğini ortaya koymak önemlidir. Dolayısıyla dönüştürücü liderliğin rekabet zekâsına olan etkisini ortaya koymak araştırmanın amaçlarından bir diğeridir.

Bahsedilen ana amaçlardan hareketle kavramlar arası ilişkileri ortaya koyan çerçeve açıklanacak ve hipotezler geliştirilecektir. Ardından otel işletmelerinin yöneticileri üzerinde uygulanan anket analiz edilecek ve bulgular diğer çalışmaların ışığında tartışılacaktır.

\section{KAVRAMSAL ÇERÇEVE}

\section{Rekabet Zekâsı}

Stratejik yönetim, aklı kullanarak rekabet üstünlüğünü ortaya çıkarabilmenin yollarını arayan bir yaklaşımdır. Bu yaklaşım içerisinde de ele alınabilecek rekabet zekâsı, çevresel unsurlar içerisinde varlığını koruyabilmenin en önemli yolunun akıldan geçtiğini gösterir. Bu nedenle çevredeki en önemli unsurlardan biri olan rakipler hakkında istihbarat bilgileri toplamak ve diğer çevre unsurlarından elde edilen bilgilerle beraber bilgi yönetiminin sağlanması rekabet zekâsının 
iki güçlü yönünü göstermektedir. Öyle ki çevredeki bilgiyi elde etmek her zaman kolay olmamakla beraber bu bilginin doğru yönetilmesi gerekmektedir.

Miller'a (2000) göre rekabet zekâsı, işletmenin geleceğini tayin edecek stratejik kararlara temel oluşturacak çevresel bilgileri edinmek ve kullanmaktır. Du Toit (2016) rekabet zekâsını bir süreç olarak ele almakta ve bu sürecin istihbarat toplama faaliyetleriyle başladığını ardından ise fırsat ve tehditlerin ortaya konulduğunu belirtmektedir. Dolayısıyla bilgi akışı sistematik olarak ele alınmakta ve rekabet avantajının kaynağı olmakta ayrıca bu üstünlüğü etik yollardan sağlamaktadır (Wright vd., 2013). Bilgilerin sistematik olarak ele alınması ve gelecekle ilgili senaryolar oluşturarak mevcut riskleri en aza indirmek rekabet zekâsının temelini oluşturmaktadır.

Bilgi yönelimi bakış açısıyla organizasyonun dış çevresindeki herhangi bir değişiklik veya gelişme, işletmelerin dikkat etmesi gereken sinyaller ve mesajlar içermektedir. Bu sinyaller zayıf (tespit edilmesi zor), kafa karıştırıcı (analiz edilmesi zor) ve sahte (gerçek değişiklikleri göstermediklerinde) olabilir. Bu nedenle stratejik hedeflerine ulaşmak ve rekabet avantajı elde etmek için işletmeler etkili istihbarat bilgileri geliştirmeli ve sürdürmeli ayrıca rekabet zekâsına yönelik bilgi yönetimi süreçlerini sürdürmelidir (Bergeron ve Hiller, 2002). Rekabet zekâsının uygulanması ile ilgili Cook ve Cook (2000) tarafından bir model geliştirilmiştir. Modele göre rekabet zekâsı genel değerlendirme ile başlamaktadır ve burada amaç rekabet zekâsı programının işletme içerisinde neden ve hangi doğrultuda kullanılacağının tespit edilmesidir. Ardından çeşitli sorunların ortaya çıarılması ve bu sorunların çözülmesinde kullanılacak kaynakların tasnifi ve yol haritasının belirlenmesidir. Daha sonra veri toparlanarak değerlendirilir. Yeterli bilgi edinilmiş ise bilgi analiz edilir fakat bilginin yetersiz olduğu tespit edilirse eksik kısımlar tespit edilerek yeniden veri toplanmalıdır. Yeterli kabul edilen bilgi, karar vericilerle paylaşılır ve karar vericilerin eyleme yönelik faaliyetlerine katkı sunması gözlenir. Karar vericilerin eylemlerinden sonra kullanılan bilginin etkinliği test edilip sonra yeniden genel değerlendirme yapılmaktadır (Kula, 2019:105). Tüm bu uygulama süreci gelişi güzel yapılmamalı diğer yandan anahtar istihbarat konuları belirlenmelidir (Murphy, 2005:56). Bu nedenle bilgiyi toplamadan önce onu istihbarata dönüştüren stratejik planlama ve yön belirleme faaliyetlerine dayanan analiz döngüsüne dikkat edilmelidir. Son olarak, rekabet zekâsının ürettiği bilgi işletmenin kullanıcı alanlarına sistematik olarak yayılması aşamasından geçecektir. Bu aşama rekabet zekâsının faaliyeti tarafından kuruma sunulacak bir ürün olarak görülebilir (Teo ve Choo, 2001). Böylece elde edilen bilgiler bir karmaşa içerisinde yığına dönüşmeyecek ve önemine göre sıralanacaktır.

Gerek kâr amacı güden gerek gütmeyen kuruluşların gerekse kamu organizasyonlarının başarıları, sadece teorik olarak yazılan planlardan ziyade karmaşık çevre unsurlarının sistematik bir şekilde fırsata dönüştürülmesine bağlıdır (Salmon ve Linares, 1999:29). Bu bağlamda rekabet zekâsı için sadece müşteri ihtiyaçlarının analizinden ziyade tüm çevre unsurlarının özelliklede rakiplerin ve işletmenin içinde bulunduğu endüstrinin analizleri önemlidir. Özellikle birincil ve ikincil kaynaklardan açık ve örtülü bilginin etik yollarla elde edilmesi ve paylaşılması ve bunun bir kültür haline getirilmesi gerekmektedir. Bu nedenle örgütsel öğrenmenin bir değişken olarak ele alınması ve incelenmesi rekabet zekâsı için elverişli bir ortamın yaratılmasına katkı sunacaktır.

\section{Örgütsel Öğrenme}

Tecrübelerin dönüşümüyle bilginin yaratıldığı bir süreç olan öğrenme uzun sürecek bir davranış değişikliği kazanmak için araştırma ve deneme yoluyla mevcut davranışları değiştirmektir (Hasebrook, 2002:4; Kim, 1993:38). Bir durum karşısında veya tekrar eden bir süreçte mevcut veya 
potansiyel davranıştaki değişim ise bireysel öğrenmedir (Probst ve Büchel, 1997:17). Sistem yaklaşımı gereği örgütler nasıl endüstrinin alt sistemi ise insan kaynakları da örgütlerin bir alt sistemidir ve faaliyetlerin yerine getirilmesinde en temel unsurdur. Dolayisiyla örgütsel öğrenmeden bahsedebilmek için öncelikle bireysel öğrenmenin gerçekleşmesi gerekmektedir. Öncelikle bireyler öğrendiklerini örgütlere aktarır ve örgütlerde dönüşerek zamanla yaratılan yeni bilgiyi bireylere aktarır (Lundberg, 1995:20). Örgütlenme fonksiyonu gereği bireyler örgütlerde bir iş biriminin, grubun veya takımın üyesi olarak çalışmaktadır. Dolayısıyla örgütsel öğrenme düzeyinde bu grupların öğrenebilme yetileri de önem arz etmektedir. Belirli bir amaca yönelmiş olan gruplar özellikle diyaloglar vesilesiyle belirli bir öğrenme sınıflanmasına mecbur kalmadan öğrenebilirler (Romme ve Dillon, 1997:67). Dolayısıyla kolektif öğrenmenin oluşturduğu sinerji ile grup halinde öğrenmenin düzeyi bireyinkinden yüksek olmaktadır. Takım üyelerinin biriktirdiği bilgiler, paylaşılan bir örgütsel hafızaya giderken en doğru kararların verilmesine yardımcı olmaktadır (Salner, 1999:489). Bu nedenle örgütlerin grup veya takım halinde öğrenmeyi sağlayacak örgütsel bir ortam oluşturmaları gerekmektedir.

Bireysel veya grup olarak öğrenmenin üzerinde bir kavram olan örgütsel öğrenme, organizasyonel bilgi ve değer değişimini esas alarak sorun çözme ve hareket kapasitesinin artırılması sürecidir (Probst ve Büchel, 1997). Diğer yandan örgütsel öğrenme çeşitli düzeylerde öğrenme olayının gerçekleştiği bir süreç olarak karşımıza çıkarken öğrenen organizasyon bu süreç sonucu ortaya çıkan yapıdır (Koçel, 2011:427). Her örgüt örgütsel faaliyetleri içerisinde öğrenir ancak bunu bir yönetsel yapı olarak ele aldığında öğrenen organizasyon olabilir.

Kıyaslama, stratejik birliktelik, deneyimleme, eğitim alma gibi çeşitli yollardan gerçekleştirilebilen örgütsel öğrenmede en az gelişmiş öğrenme yapısı bilen örgütlerdedir. Klasik yönetim yapısına sahip bilen örgütler, çevresel değişime tepki olarak değişmektedirler (Bayraktaroğlu ve Kutanis, 2003). Örgütsel açıdan geleceğin öngörülmesi ve verimliliğin artırılması için değişmez kuralların hâkimiyet ve baskısını ortadan kaldıran örgütler ise anlayan örgütlerdir (Seymen ve Bolat, 2002:102). Sorunların çözümü için yönetsel bir teknik oluşturarak çevreye uyum sağlayan örgütler, düşünen örgütler olarak ortaya çıkmaktadır. Son aşamada ideal olarak kabul edilen ve kazanılan tecrübenin devamlı olarak ele alınmak üzere bilgi olarak yorumlanması, yayılması ve amaçlarla ilişkilendirilmesi süreci öğrenen örgütleri ifade etmektedir (Garvin, 1999). Senge (2000)'e göre öğrenen örgütler, işgörenlerin istenilen sonuçları yaratmak için kapasitelerini ve yeteneklerini sürekli olarak geliştirdikleri, yeni düşünce tarzlarının hayat bulduğu, ortak hedeflerin oluşturulduğu ve insanların beraber öğrendikleri organizasyonlardır.

Öğrenen örgütlerin tam olarak çalışabilmesi için beş disiplinden bahseden Senge'ye (2006) göre örgütler paylaşılan vizyon ile geleceğe yönelik ortak değerler ortaya koymakta ve işgörenler öğrenme için gerekli motivasyon ve odaklanmayı sağlamaktadır. İkinci disiplin olan kişisel yetkinlik ile bireyler paylaşılan vizyona ulaşabilmek için yaşam boyu öğrenme çabası gösterme düzeyine gelmektedir. Bireylerin zihninde oluşan köklü düşünceler, semboller, resimler ve imgeler insanların düşüncelerini etkileyen zihni modeller oluşturmaktadır. Üçüncü disiplin olan zihinsel modellerde bireyleri belirli kalıpların hâkimiyetine girmekten kurtararak öğrenmeye açık yön oluşturulması planlanmaktadır. Dördüncü disiplin bir döngü içerisinde gerçekleşen durumların bütün olarak algılanabildiği sistem düşüncesidir. Sistem düşüncesi ile bir bütünü oluşturan parçaların nasıl beraber hareket ettiği anlaşılmaktadır. Son olarak beşinci disiplin takım halinde hareket etme disiplinidir. Buna göre işgörenler hedeflere ulaşırken takım halinde hareket ederek birlikte düşünme ve öğrenme kapasitesi kazanırlar.

Örgütsel yapı içerisinde rekabet zekâsı ve öğrenen örgütlere en büyük katkıyı yapacak olan hiç şüphesiz yöneticilerdir ve bu bağlamda onların liderlik biçimlerini ortaya koymak mühimdir. 
Modern liderlik tarzlarının en önemlilerinden birisi olan dönüştürücü liderliğin bu kavramlarla beraber değerlendirilmesi amaçlanmıştır.

\section{Dönüştürücü Liderlik}

Grupların veya kişilerin amaçlarını gerçekleştirmek için organize olmuş toplulukların faaliyetlerine etki etme süreci, liderlik olarak ifade edilmektedir (Schein, 1992:2). Bu nedenle liderler takipçilerini amaçlara ulaşmaya teşvik eder ve onları eyleme geçirirler (Burns, 1978:425). Liderler takipçilerini eyleme geçirmede çeşitli yöntemler kullanmaktadır ve bu liderlik biçimleri uzun yıllardır araştırmacılar tarafından incelenmektedir. Bu yöntemlerden birisi olan dönüştürücü liderlik ise son 20 yıl içerisinde örgütlerde çok fazla kullanılan modern bir liderlik biçimidir. İşörenler ile yakın bağlar kurmak ve onlar arasındaki farklılıklara önem vererek bu doğrultuda onları zihinsel olarak etkilemek, uyarmak ve onlar arasında paylaşılabilen vizyon oluşturmak ve benimsetmek dönüştürücü liderlik olarak tanımlanır (Lowe vd., 1996:395). Dönüştürücü liderler, yaptırım güçlerini çok etkili olarak alçak gönüllülükle ortaya koyarlar ve örgüt içerisinde doğru insanlarla çalışırlar (Collins, 2004:15). Dolayısıyla insanları motive ederler ve beklenenden daha fazla verim elde ederler.

Dönüştürücü liderlik doğası gereği bir takım karakteristik özellikler barındırmaktadır. Bunlardan ilki, ileri görüşlülük olarak da adlandırılan uzun dönemli görülmek istenen yere yönelik oluşturulan planların paylaşıldığı ortak vizyon oluşturmaktır (Schermerhorn, 1993:426). İkincisi ise rekabetin artmasıyla beraber örgütlerde değeri daha çok artan takipçilerini güçlendirme kavramıdır. Güçlendirme, rekabette üstünlügü sağlayabilmek için yöneticilere tanımlanan karar ve onay mekanizmalarının, belirli bir eğitim ve uzmanlık karşılığında görevi yerine getiren çalışanlara bırakılması ve onların takım halinde organize olabilmesini ifade etmektedir (Yıldırım ve Karabey, 2016). Dönüştürücü liderliğin özelliklerinden üçüncüsü, takipçilerin risk alma, yenilikçi, yaratıcı ve rasyonel olmaları yönünde desteklendiği ve bu doğrultuda ihtiyaçları olan eğitim ve geliştirme faaliyetlerinin önemsendiği entelektüel uyarımdır. Böylelikle takipçilerin fikirler ve nesneler arasında ilişki kurması sağlanır (Bolt, 2000; Güler, 2019). Bu durum dinamik çevrede rekabet üstünlügünü sağlama aracı olan yaratıcılık için önemli bir faktördür. Diğer yandan yüksek motivasyon, güvenirlik, esnek yönetim gibi özellikleri de sıralamak mümkündür.

\section{Kavramlar Arası İlişkiler}

Fiol ve Lyles (1985), yaptı̆̆ a araştırmadan elde ettiği sonuçlara göre örgütlerin stratejik duruşlarının öğrenme kapasitelerini belirlediğini ifade etmiştir. Buna göre stratejinin hedef ve amaçlara ulaşmak için uygun eylemlerin gerçekleştirilmesi, çevrenin algılanışı ve yorumlanışı gibi düzlemler sunarak öğrenmeye etki etmektedir. Benzer olarak algılanan stratejik alternatifler örgütün öğrenme kapasitesinin bir fonksiyonu olarak ortaya çıkmaktadır. Porter (2000)'e göre rekabet üstünlüğü sağlayacak stratejik uygulamalar olmaksızın öğrenme etkin bir şekilde sürdürülemez. Slocum ve diğerleri (1994) mahallî pazarları inceledikleri araştırmalarında öğrenme ve esneklik olmadan rekabet üstünlüğü sağlamanın imkânsız olduğunu ortaya koymuştur. Ayrıca araştırmanın sonuçlarına göre öğrenme yenilenebilir rekabet üstünlüğünün rotası olarak mahallî pazarlarda rekabet stratejisinin yerine kadar geçmektedir. Sinkula'nın (1994) araştırmasında özellikle rekabet zekâsı içerisinde değerlendirilen istihbarat ve buna bağlı olarak oluşan pazar bilgisi örgütsel öğrenmenin dört ana sürecinden etkilenmektedir. Bu araştırmalardan hareketle örgütsel öğrenmeyle bilgiyi elde etme, işleme, saklama ve paylaşma 
gibi ortak özellikleri barındıran rekabet zekâsının örgütsel öğrenmeden olumlu etkilendiği düşünülmektedir.

Dönüştürücü liderlerin takipçileriyle paylaşılan ortak değerler ve vizyon oluşturması, motive etmesi, güçlendirme ile risk alma ve yaratıcılığı artırması nedeniyle öğrenme düzeyini ve rekabet üstünlüğü sağlayabilmeyi artırdığı birçok araştırmada tespit edilmiştir (Avolio vd., 1999; Bass, 1990). Bass ve diğerlerinin 2003 yılında yaptığı araştırmada dönüştürücü liderlerin etkileyici duruşlarıyla örgüt içerisinde iletişim kanallarını güçlü bir şekilde açması ve bunun yanında saygı, güven ve bilgi paylaşımı düzeylerinin yükselmesi ile zekâ düzeyinin de yükseldiği tespit edilmiştir. Alowais (2019) göre dönüştürücü liderlik örgütsel bilgi kapasitesini dolaylı yollardan artırarak örgütlerin küresel çapta rekabet üstünlüğü sağlayacak bir yeteneğe kavuşmasını sağlar. $\mathrm{Bu}$ araştırmalardan hareketle dönüştürücü liderliğin örgütsel öğrenme düzeyini ve rekabet zekâsını doğrudan ve dolaylı olarak artırdığı düşünülmektedir.

\section{YÖNTEM}

Bu kısımda araştırmanın modeli, hipotezleri, örneklem ve ölçeğin geliştirmesine ilişkin bilgiler verilecektir.

\section{Araştırmanın Modeli ve Hipotezler}

Yapılan literatür taraması ve kavramlar arası ilişkilerin ışığında aşağıdaki hipotezler geliştirilmiştir.

\section{Hı: Dönüştürücü liderlik, rekabet zekâsını anlamlı ve olumlu olarak etkiler.}

$\mathrm{H}_{2}$ : Dönüş̧ürücü liderlik, örgütsel öğrenmeyi anlamlı ve olumlu olarak etkiler.

$\mathbf{H}_{2 a}$ : Dönüştürücü liderlik, öğrenmeye bağlılığı anlamlı ve olumlu olarak etkiler.

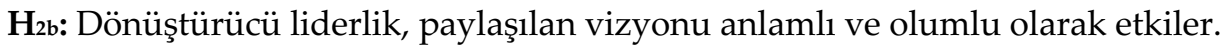

H2c: Dönüştürücü liderlik, açı görüşlülüğü anlamlı ve olumlu olarak etkiler.

$\mathrm{H}_{3}$ : Örgütsel Öğrenme, rekabet zekâsını anlamlı ve olumlu olarak etkiler.

$H_{3 a}$ : Öğrenmeye bağlılık, rekabet zekâsını anlamlı ve olumlu olarak etkiler.

$\mathbf{H}_{3 \mathrm{~b}}$ : Paylaşılan vizyon, rekabet zekâsını anlamlı ve olumlu olarak etkiler.

$\mathbf{H}_{\text {3c: }}$ Açık görüşlülük, rekabet zekâsını anlamlı ve olumlu olarak etkiler.

H4: Dönüştürücü liderlik, rekabet zekâsını anlamlı ve olumlu olarak etkilerken örgütsel öğrenme aracı rol oynar.

H4a: Dönüştürücü liderlik, rekabet zekâsını anlamlı ve olumlu olarak etkilerken öğrenmeye bağlllık aracı rol oynar.

H4b: Dönüştürücü liderlik, rekabet zekâsını anlamlı ve olumlu olarak etkilerken paylaşılan vizyon aracı rol oynar.

H4c: Dönüştürücü liderlik, rekabet zekâsını anlamlı ve olumlu olarak etkilerken açık görüşlülük aracı rol oynar.

Değişkenler arasındaki ilişkiyi özetleyen model Şekil 1'de verilmiştir. 


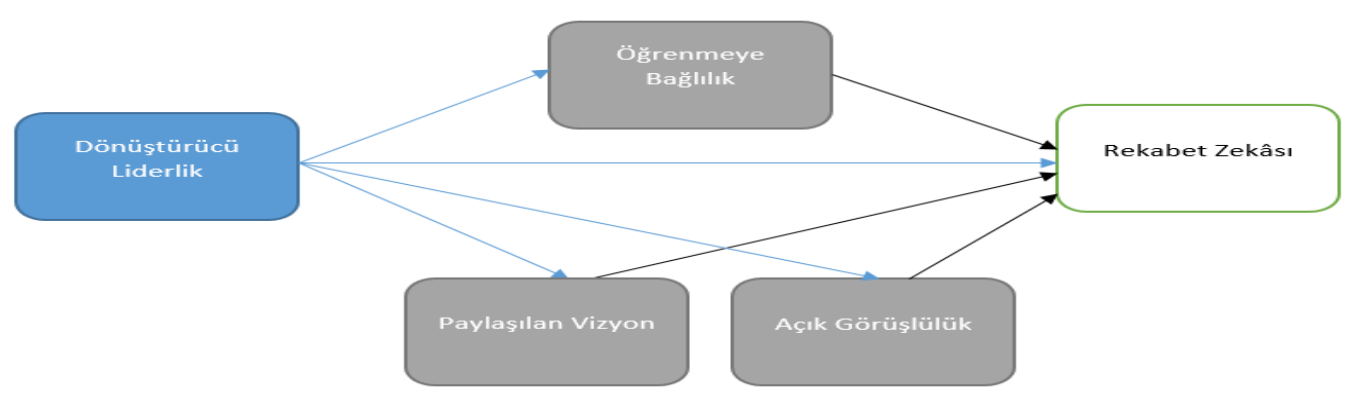

Şekil 1. Araştırmanın Modeli

\section{Evren ve Örneklem}

Aralarında yoğun rekabetin yaşandığg Muğla İlinin Bodrum Turizm Bölgesinde faaliyet gösteren 5 yıldızlı oteller araştırma için evren olarak seçilmiştir. Buradaki birçok otel uzun yılların verdiği tecrübeyle öğrenme düzeyine bağlı olarak belirli rekabet stratejileri sürdürmektedir. Dolayısıyla bu bölgedeki 5 yıldızlı otellerin stratejilerinde büyük söz sahibi olan ve tesadüfi olarak seçilmiş alt, orta, üst düzey yöneticiler üzerinde araştırma yapılmıştır. Araştırma için 220 anket 2019 yılı yaz sezonunda yüz yüze yapılmış ve eksik bilgisi olan anketler çıkarıldıktan sonra 208 anket analize tabi tutulmuştur.

\section{Araştırma Ölçeğinin Geliştirilmesi}

Araştırmada ölçek olarak anket yöntemi seçilmiştir. Anketler seçilirken uluslararası kabul görmüş çalışmalardan elde edilen ve Türkiye'de geçerliliği güvenirliği sağlanan ölçeklerden ifadeler alınmıştır.

Dönüştürücü Liderlik: Dönüştürücü liderlik için Carless ve diğerlerinin (2000) geliştirdiği tek boyutlu 7 soruluk anket kullanılmıştır. Anketi daha önce Naktiyok ve İşcan (2019) Türkiye'de Turizm Sektöründe kullanmış yüksek güvenirlik ve geçerlilik elde etmiştir.

Örgütsel Öğrenme: İşletmelerin öğrenme düzeyini ölçmek için Baker ve Sinkula'nın 1999 yılında geliştirdiği öğrenmeye bağlllık, paylaşılan vizyon ve açık görüşlülük olarak üç alt boyutta değerlendiren ölçek seçilmiştir. Ölçeği Türkiye'de Timuroğlu ve diğerleri (2016) kullanmış yüksek güvenirlik ve geçerlilik elde etmiştir.

Rekabet Zekâsı: Rekabet zekâsı ölçeğini Kula 2019 yılında Day ve Wensley (1988), Dickson (1992), Sawka vd., (1996), Hamel ve Parahalad (1996), Li ve Calantone (1998), Prescott (1999), Guimaraes (2000), Teo ve Choo (2001), Qiu (2008), Saayman vd., (2008), Dishman ve Calof (2008), Wright vd., (2013), Köseoğlu vd., (2016), Hall ve Bensoussan'nın (2007) akademik kitabı ile Dugal (1996), Hesford (1998), Grooms (2001), Chen'in (2012) çalışmalarından yararlanılarak geliştirmiştir. Kula (2019) araştırmasında rekabet zekasını kapsam ve süreç olarak 7 alt boyutta değerlendirmiştir. Araştırmamızda değişkenler arası ilişkinin net ortaya konulabilmesi için ilgili teorik tarama sonucunda 11 soru ile tek alt boyut olarak ele alınmıştır. Ölçeklerin tümü 5'li Likert tipindedir.

Ölçekler için güvenilirlik analizi yapılmış olup cronbach alfa değerleri toplam örgütsel öğrenme için 0,946, öğrenmeye bağl1lık için 0,917, paylaşılan vizyon için 0,836, açık görüşlülük için 0,917, dönüştürücü liderlik için 0,907 ve rekabet zekâsı için 0,926 bulunmuştur. Kullanılan ölçeklerin oldukça güvenilir bulunduğu söylenebilir. 
Kullanılan ölçeklerin yapı geçerliliğini ortaya koymak amacıyla doğrulayıcı faktör analizi yapılmış olup analiz sonuçları sonraki bölümde Tablo 2 ve Tablo 3'te raporlanmıştır. Sonuçta tüm ölçeklerin yüksek düzeyde geçerlilik sergilediği belirlenmiştir. Ancak LISSEL programının modifikasyon yönlendirmesi gereği ölçeklerde her biri için 5'i geçmemek üzere bazı ifadeler birbirine bağlanmıştır. Bu durum ile ilgili bilgi şeklin altında gösterilecektir.

Yukarıda ölçüm şekilleri açıklanan bağımlı ve bağımsız değişkenlere ilaveten bu çalışmada yaş, cinsiyet, eğitim düzeyi, işyerindeki kıdem ve yönetsel görev demografik değişken olarak ele alınmış ve katılımcı profilinin daha iyi anlaşılması hedeflenmiştir.

\section{ANALIZ ve BULGULAR}

Tablo 1'de araştırmaya katılan çalışanlarla ilgili demografik bilgiler sunulmuştur.

Tablo 1: Katılımcılara İlişkin Demografik Veriler

\begin{tabular}{llll|llll}
\hline ÖZELLIK & & $f$ & (\%) & ÖZELLIK & & $f$ & (\%) \\
\hline \multirow{4}{*}{ Yaş } & 25 veya altı & 18 & 8,65 & Cinsiyet & Kadın & 97 & 46,63 \\
& $26-30$ & 31 & 14,91 & & Erkek & 111 & 53,37 \\
\cline { 5 - 8 } & $31-35$ & 42 & 20,19 & & Önlisans veya altı & 41 & 19,71 \\
& $36-40$ & 57 & 27,40 & Ĕgitim & Lisans & 112 & 53,85 \\
& 40 'ın üzeri & 60 & 28,85 & & Lisansüstü & 55 & 26,44 \\
\hline \multirow{2}{*}{ Medeni } & Evli & 125 & 60,10 & & $0-5$ & 47 & 22,59 \\
& Bekâr & 83 & 39,90 & Kurum & $6-10$ & 56 & 26,92 \\
& & & & Kidemi & $11-15$ & 72 & 34,62 \\
& & & & & 16 yıl ve üzeri & 33 & 15,87 \\
\hline
\end{tabular}

Tablo 1'e göre araştırmaya katılanların \% 8,65'i 25 yaşın altında, \% 14,91'i 26-30 yaş aralığında, \% 20,19'u 31-35 yaş aralığında, \% 27,40'1 36-40 yaş aralığında ve \% 28,85'i 40 yaşını üzerindedir. Araştırmaya katılanların \% 46,63'ü kadın ve \% 53,37'si erkektir. Katılımcıların, \% 19,71'i önlisans veya altı, \% 53,85'i lisans ve \% 26,44'ü lisansüstü mezunudur. Katılımcıların \% 22,59'u 0-5 yıldır, $\%$ 26,92'si 6-10 yıldır, \% 34,62'si 11-15 yıldır ve \% 15,87'si 16 yıl ve üzeri süredir mevcut otelde çalışmaktadır. Son olarak katılımcıların \% 60,10'u evliyken \% 39,90'ı bekârdır.

Doğrulayıcı faktör analizinden önce verilerin normal dağılıma uygunluk gösterip göstermediğini test etmek için çarpıklık değerleri incelenmiştir. Normal dağılıma uyan değişkenler için en yüksek kestirim (maximum likelihood), buna uymayan karşıllk tedbiri değişkeni için de ağırlıklandırılmış en küçük kareler (weighted least squares) yöntemiyle doğrulayıcı faktör analizi yapılmıştır. Doğrulayıcı faktör analizlerinin sonuçları ve uyum indeksleri kabul değerleri sırasıyla Tablo 2 ve Tablo 3'te gösterilmiştir:

Tablo 2'ye göre araştırmada yer alan değişkenlerin doğrulayıcı faktör analizi sonucunda genel olarak iyi uyum sergilediği görülmüştür. Sadece örgütsel öğrenmenin AGFI değeri 0,87 ve rekabet zekâsının AGFI değeri 0,89 olarak çıkmıştır ve bunlarda birçok araştırmaya göre kabul 
edilebilir uyum aralığındadır (Taşgın ve Korucuk, 2019; Akbaba, 2019). Şekil 2, 3 ve 4'te standardize faktör yükleri verilmiştir.

Tablo 2: Doğrulayıcı Faktör Analizleri Sonucunda Elde Edilen Uyum İyiliği İndeksleri

\begin{tabular}{lcccccccc}
\hline Değişken & \multicolumn{2}{l}{ Değerler } & & & & & & \\
& $\chi^{2}$ & $(\mathbf{s d})$ & $\chi^{2} / \mathbf{s d}$ & CFI & NFI & NNFI & AGFI & RMSEA \\
& 17,53 & 11 & 1,59 & 1,00 & 0,99 & 0,99 & 0,94 & 0,054 \\
$\begin{array}{l}\text { Dönüştürücü } \\
\text { Liderlik }\end{array}$ & 107,20 & 46 & 2,33 & 0,99 & 0,98 & 0,98 & 0,87 & 0,080 \\
$\begin{array}{l}\text { Örgütsel } \\
\text { Öğrenme }\end{array}$ & & & & & & & & \\
Rekabet Zekâsı & 82,86 & 39 & 2,12 & 0,99 & 0,97 & 0,98 & 0,89 & 0,074 \\
\hline
\end{tabular}

Tablo 3: Uyum İndeksleri Kabul Değerleri

\begin{tabular}{lll}
\hline Kısaltma & Anlamı & Kabul değeri \\
\hline$\chi^{2}$ & Ki kare & - \\
\hline $\mathrm{Sd}$ & Serbestlik derecesi & - \\
\hline$\chi^{2 / s d}$ & Ki kare/ serbestlik derecesi & $\leq 2^{\mathrm{a},}, \leq 5 \mathrm{~b}$ (a: çok iyi uyum, b: iyi uyum) \\
\hline RMSEA & Yaklaşık Hataların Ortalama Karekökü & $0,05<$ (tolerans 0,08) \\
\hline CFI & Artmalı Uyum İyiliği İndeksi & $0,90 \leq$ \\
\hline NFI & Normlaştırılmış Uyum İyiliği İndeksi & $0,90 \leq$ \\
\hline NNFI & Normlaştırılmamış Uyum İyiliği İndeksi & $0,90 \leq$ \\
\hline AGFI & Düzeltilmiş İyilik Uyum İndeksi & $0,90 \leq$ \\
\hline
\end{tabular}

Kaynak: Meydan ve Şeşen, 2011. 


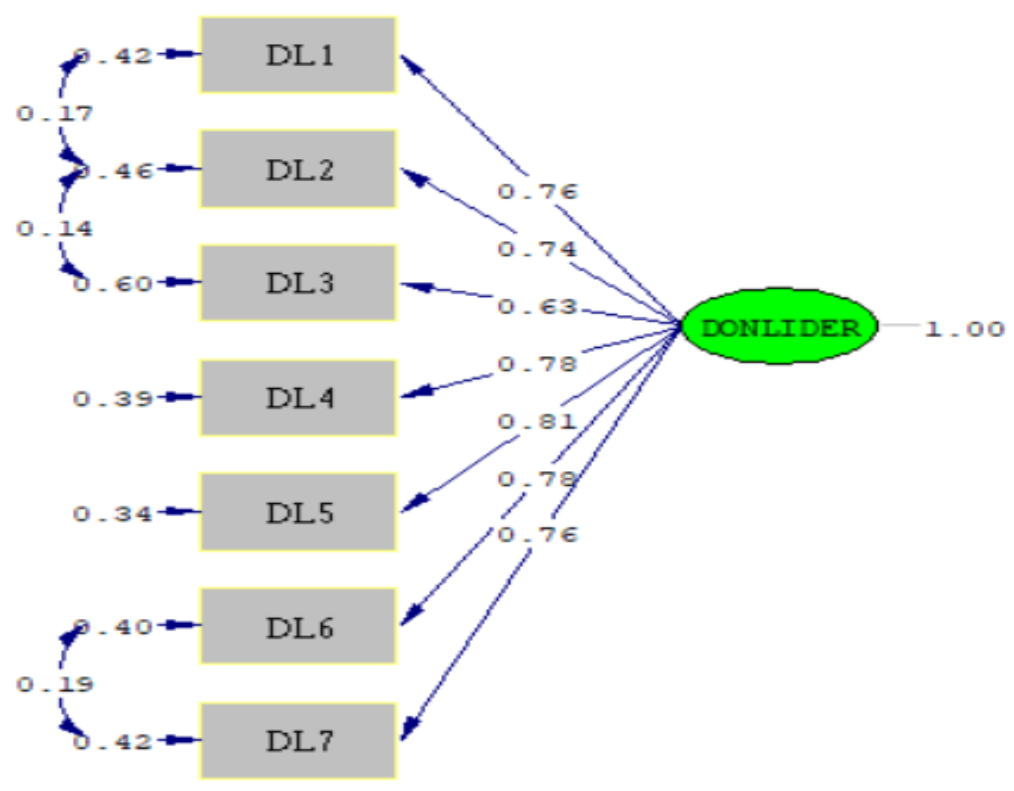

17.53, df=11, P-value=0.09309, RMSEA=0.054

Şekil 2: Dönüştürücü Liderliğe İlişkin Standardize Yüklere Ait LISREL Çıktısı

Şekil 2'ye göre dönüştürücü liderliğge ilişkin hiçbir ifade ölçekten çkarılmamıştır. Tüm ifadelerin standardize yükleri 0,50 'nin üzerinde ve 1'in altındadır. LISREL programının yönlendirmesi gereği DL1-DL2, DL2-DL3 ve DL6-DL7 ifadeleri bağlanmıştır. Dönüştürücü liderlik alt boyutu DONLIDER ve soruları DL olarak kısaltılmıştır. 


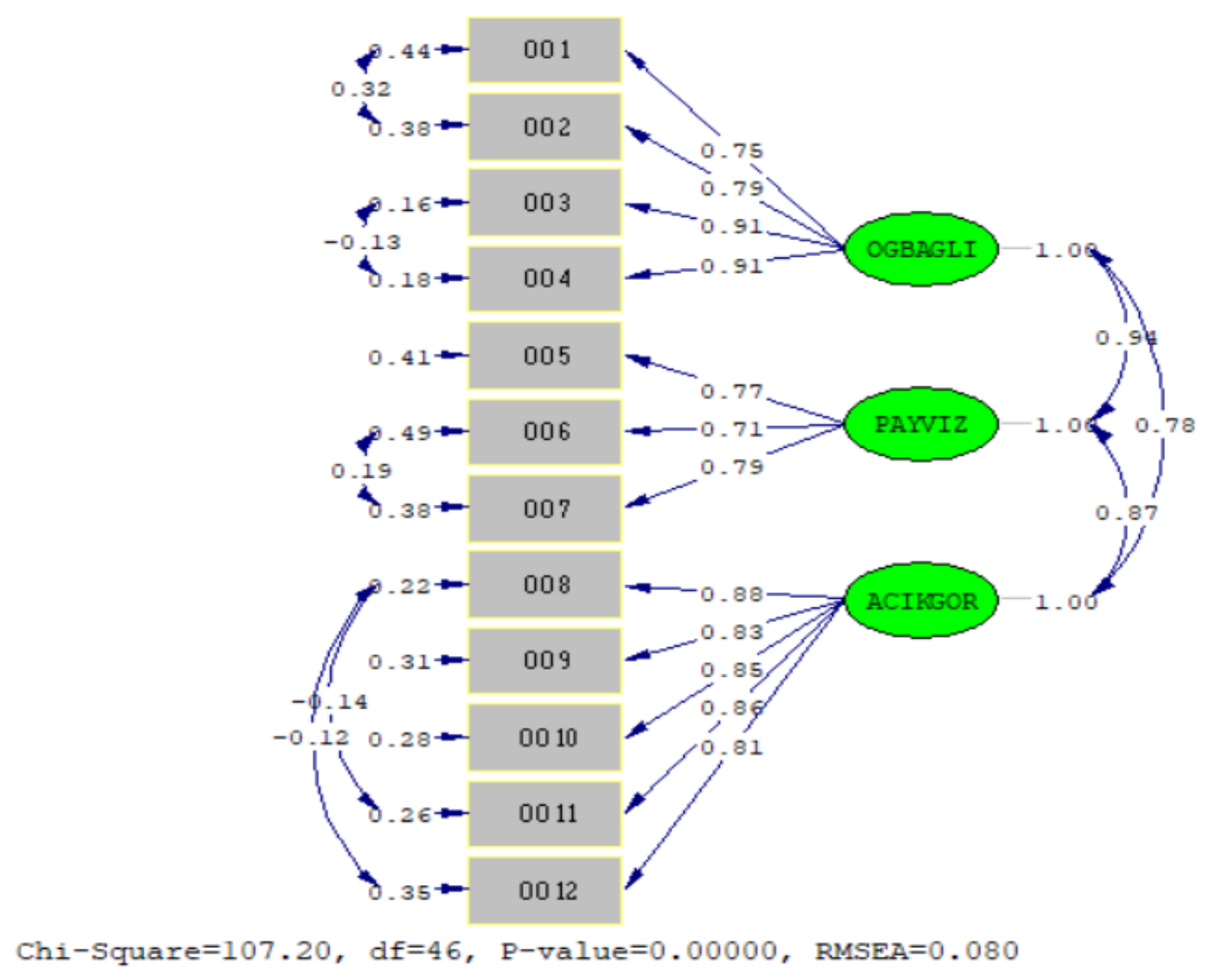

Şekil 3: Örgütsel Öğrenmeye İlişkin Standardize Yüklere Ait LISREL Çıktısı

Şekil 3'e göre örgütsel öğrenmeye ilişkin hiçbir ifade ölçekten çıkarılmamıştır; fakat paylaşılan vizyonun bir ifadesi açık görüşlülüğe kaymıştır. Tüm ifadelerin standardize yükleri 0,50'nin üzerinde ve 1'in altındadır. LISREL programının yönlendirmesi gereği OO1-OO2, OO3-OO4, OO6-OO7, OO8-O11 ve OO8-O12 ifadeleri bağlanmıştır. Öğrenme bağlllı̆̆1 alt boyutu OGBAGLI, paylaşılan vizyon alt boyutu PAYVIZ ve açık görüşlülük alt boyutu ACIKGOR ve genel olarak soruları OO olarak kısaltılmıştır. 


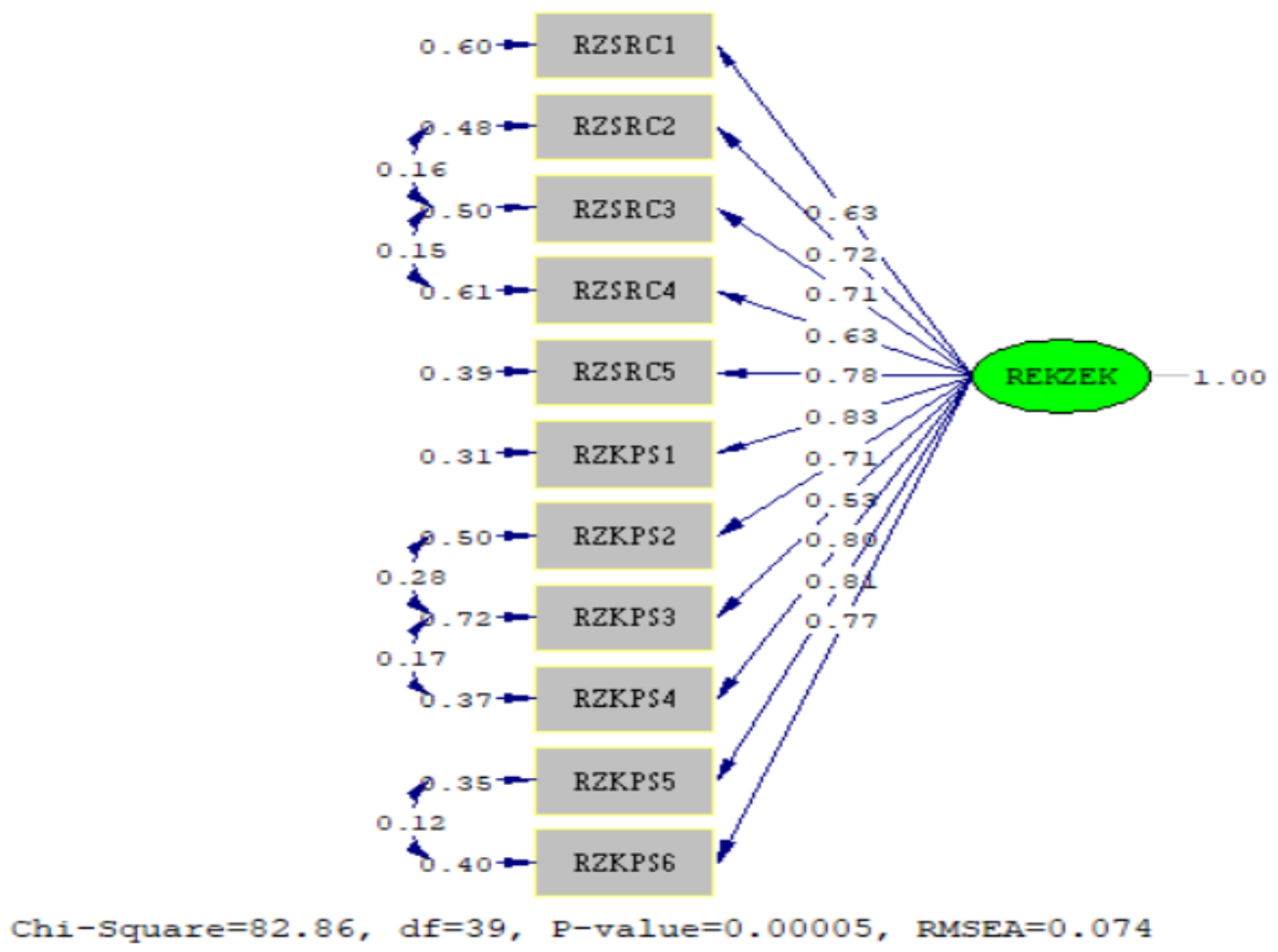

Şekil 4: Rekabet Zekâsına İlişkin Standardize Yüklere Ait LISREL Çıktısı

Şekil 4'e göre rekabet zekâsına ilişkin hiçbir ifade ölçekten çıkarılmamıştır. Tüm ifadelerin standardize yükleri 0,50'nin üzerinde ve 1'in altındadır. LISREL programının yönlendirmesi gereği RZSRC2-RZSRC3, RZSRC3-RZSRC4, RZKPS2-RZKPS3, RZKPS3-RZKPS ve RZKPS5RZKPS6 4ifadeleri bağlanmıştır. Rekabet zekâsı alt boyutu REKZEK ve süreç soruları RZSRC ve kapsam soruları RZKPS olarak kısaltılmıştır ve tek boyutta değerlendirilmiştir.

Tablo 4: Değişkenlere İlişkin Tanımlayıcı İstatistikler, Korelasyon Katsayıları

\begin{tabular}{|c|c|c|c|c|c|c|c|}
\hline Değişken & Ort. & St.Sapma & 1 & 2 & 3 & 4 & 5 \\
\hline $\begin{array}{l}\text { 1-Dönüştürücü } \\
\text { Liderlik }\end{array}$ & 3,9238 & 0,79841 & 1 & & & & \\
\hline $\begin{array}{l}\text { 2-Öğrenmeye } \\
\text { Bağlllık }\end{array}$ & 3,6526 & 1,09807 & $0,688^{* *}$ & 1 & & & \\
\hline $\begin{array}{l}\text { 3-Paylaşılan } \\
\text { Vizyon }\end{array}$ & 3,7676 & 0,99594 & $0,707^{* *}$ & $0,795^{* *}$ & 1 & & \\
\hline 4-Açık Görüşlülü̈k & 3,9192 & 0,86388 & $0,753^{* *}$ & $0,678^{* *}$ & $0,728^{* *}$ & 1 & \\
\hline 5-Rekabet Zekâsı & 3,9650 & 0,72434 & $0,636^{* *}$ & $0,471^{* *}$ & $0,603^{* *}$ & $0,652^{* *}$ & 1 \\
\hline
\end{tabular}

${ }^{* *}$ Korelasyon 0,01 düzeyinde anlamlıdır. *Korelasyon 0,05 düzeyinde anlamlıdır. 
Tablo 4 incelendiğinde, dönüştürücü liderlik, öğrenmeye bağlllık, paylaşılan vizyon, açık görüşlülük ve rekabet zekası arasında anlamlı ve güçlü ilişkiler tespit edilmiştir. Tüm ilişkiler 0,01 düzeyinde anlamlıdır.

Araştırma modelindeki değişkenlerin yapısal özellikleri doğrulandıktan sonra, yol analiziyle bir bütün olarak modelin ve hipotezlerin doğrulanıp doğrulanmadığı test edilmektedir. Başlıca uyum iyiliği değerlerini ve regresyon katsayılarını gösteren yol analizi sonuçları Şekil 5'te verilmiştir:

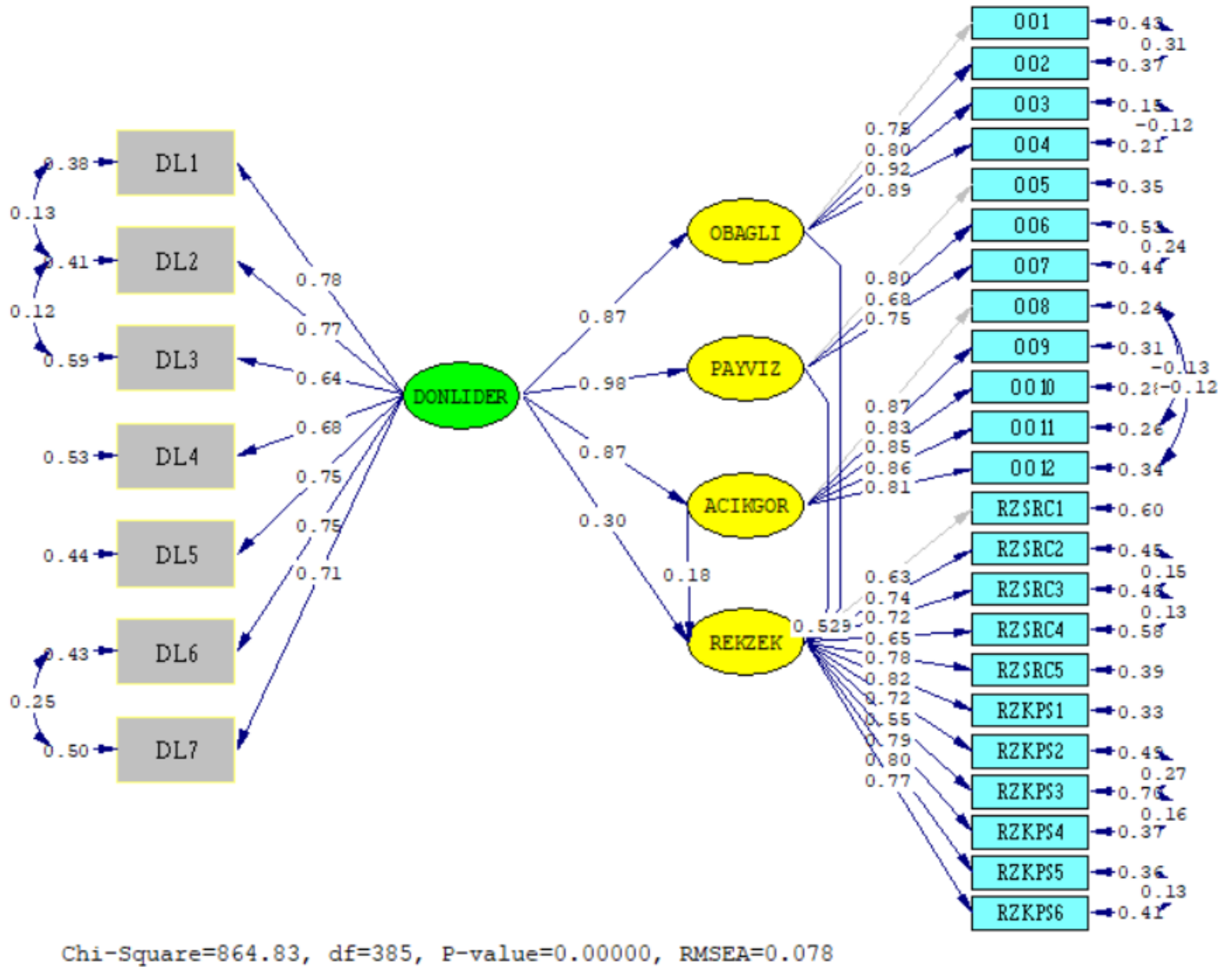

Şekil 5: Araştırma Modeline İlişkin Yol Analizi Standardize Değerler

Şekil 5' e göre DFA'daki tüm ifade bağlamaları Yapısal Eşitlik Modelinde aynen uygulanmıştır. Standardize yüklerin 0,50'nin üstünde 1'in altında olduğu gözükmektedir. Yapısal eşitlik modellemesinde önce doğrudan etkiler ölçülmüş ardından aracı değişkenlere bakılmıştır. Doğrudan etkide dönüştürücü liderliğin rekabet zekâsına ve örgütsel öğrenmenin tüm alt boyutlarına anlamlı ve olumlu etkileri bulunmaktadır. Örgütsel öğrenmenin üç alt boyutunun da rekabet zekâsına anlamlı ve olumlu etkisi tespit edilmiştir. Ayrıca örgütsel öğrenmenin alt boyutları olan öğrenmeye bağlılık, paylaşılan vizyon ve açık görüşlülük aracı etkilerine bakıldığında dönüştürücü liderliğin doğrudan anlamlı olan etkisi üç alt boyut ayrı ayrı devreye girdiğinde 7,88 olan t-değerini 1'in altına düşürerek anlamsız hale getirmiştir. Bu nedenle üç alt boyutunda tam aracılık etkisi bulunmaktadır.

Yapısal Eşitlik Modelinin kabulüne ilişkin uyum indeksi sonuçları aşağıda verilmiştir. 
Tablo 5: Yapısal Eşitlik Modellemesi Analizleri Sonucunda Elde Edilen Uyum İyiliği İndeksleri

\begin{tabular}{|c|c|c|c|c|c|c|c|c|c|}
\hline \multirow[t]{2}{*}{ Değişken } & & \multicolumn{8}{|c|}{ Değerler } \\
\hline & & $\chi^{2}$ & (sd) & $\chi^{2} / \mathrm{sd}$ & CFI & NFI & NNFI & AGFI & RMSEA \\
\hline $\begin{array}{l}\text { Araştırma } \\
\text { Değerleri }\end{array}$ & YEM & 864,83 & 385 & 2,24 & 0,98 & 0,96 & 0,97 & 0,85 & 0,078 \\
\hline
\end{tabular}

Tablo 5'te yazılan YEM uyum indekslerine göre model kabul edilmektedir. Sonuç olarak bütün hipotezler kabul edilmiştir.

\section{SONUÇ ve TARTIŞMA}

Dönüştürücü liderliğin rekabet zekâsına etkisinde örgütsel öğrenmenin aracllık rolünü incelemek amacıyla gerçekleştirilen araştırma için beş yıldızlı otellerde çalışan alt, orta, üst düzey yöneticilere 208 adet anket yapılmış ve ifadelere verilen cevaplar LISREL paket programında analiz edilmiştir. Analizden elde edilen sonuçlara göre dönüştürücü liderliğin ortalaması 3,92, öğrenmeye bağlılığın ortalaması 3,65, paylaşılan vizyonun ortalaması 3,76, açık görüşlülüğün ortalaması 3,91 ve rekabet zekâsının ortalaması 3,96 olarak tespit edilmiştir. Örneklemdeki otellerde genel olarak dönüştürücü liderlik, örgütsel öğrenme ve rekabet zekâsı düzeyi yüksek çıkmıştır. Köseoğlu 2016 yılında Amerika Birleşik Devletlerindeki otellerin yöneticileriyle rekabet zekâsı farkındalı̆̆ı üzerine bir araştırma yapmış ve kavramın farkındalığı düşük çıkmıştır. Yöneticiler her ne kadar kavramın tanımın bilmese de bilgi ve istihbarat edinme faaliyetlerini sıklıkla uyguladıkları görülmüştür. Daha açık bir ifade ile yöneticiler rekabet zekâsı kavramının tanımını çoğunlukla bilmese bile kavrama ilişkin faaliyetleri yerine getirmektedirler. Bu araştırmada analizin yapıldığı bölge itibariyle yüksek rekabet içerisinde faaliyet gösteren oteller tecrübe sahibi, nitelikli personelle çalışan otellerdir. Bunun doğal bir sonucu olarak örgütler gerek bulundukları sektörden gerekse iç dinamiklerinden öğrenme işlemlerini gerçekleştirmektedirler. Üstelik şiddetli rekabette ayakta kalabilmek için birbirlerinden bilgi ve istihbarat elde edebilme çabası içerisindedirler. Böylece zorlu çevre şartlarına uyum sağlayarak ve hatta çevreyi dönüştürerek hayatta kalmaktadırlar.

Araştırmanın bağımsız değişkeni olan dönüştürücü liderliğin rekabet zekâsına doğrudan olumlu etkisinin olduğu tespit edilmiştir. Collins (2004) araştırmalarına göre dönüştürücü liderler liyakata önem vererek doğru insanlarla çalışırlar ve bu verimlilik açısından önemlidir. Yapılan birçok araştırma göstermektedir ki dönüştürücü liderler, çalışanlara ilham kaynağı olmakta ve onların kişisel gelişimlerine katkıda bulunmaktadırlar. Ayrıca işgörenlerine vizyon kazandırarak onların kendilerine olan güven derecelerini artırmakta ve onları motive etmektedirler (Walumba vd., 2005:235; Tse vd., 2008:5; Riaz vd., 2011:43; Tims vd., 2011:121). Dönüştürücü liderler sayesinde söz konusu ortamın oluşması ile rekabet üstünlügünün sağlanması için elde ettikleri bilgi ve istihbarat ışığında işletmelerin geleceği tahmin edebilecek öngörülerde bulunabilme becerilerini artırdıkları söylenebilir. Bu nedenle turizm işletmelerine strateji oluştururken ve faaliyetleri yerine getirirken dönüştürücü liderlik sitillerinin uygulanması önerilmektedir.

Dönüştürücü liderliğin diğer bir olumlu etkisi de örgütsel öğrenmenin üç alt boyutu olan öğrenmeye bağlılık, paylaşılan vizyon ve açı görüşlülük üzerinedir. Desphande ve diğerleri (1993) bilginin örgüt içerisinde bireylerin zihinsel kalıpları tarafından yorumlandığını ortaya koymuştur ve buna bağlı olarak paylaşılan değerler, inançlar ve liderlik tipi gibi değişkenlere 
bağlı olarak örgütsel öğrenme değişir. Dönüştürücü liderlik anlayışında ileri görüşlülük, ortak vizyon, güçlendirme, risk alma, yaratıcılık gibi karakteristik özellikler örgütsel olarak öğrenme düzeyine önemli katkılar sunmaktadır.

Öğrenmeye bağlılık, paylaşılan vizyon ve açık görüşlülük alt boyutlarıyla örgütsel öğrenme, rekabet zekasını doğrudan olumlu olarak etkilemiştir. Kula (2019) otomotiv sektöründe yaptığ araştırmada stratejik düşüncenin alt boyutu olarak değerlendirdiği vizyonun rekabet zekâsını olumlu etkilediğini tespit etmiştir. Baker ve Sinkula' ya (2002) göre öğrenme yönlülük örgütün bilgiye verdiği değerin yani öğrenme bağlllığının ürünüdür. Morgan ve Turnell'e (2003) göre öğrenme yönlülük gibi örgüt içi davranışlar rekabet avantajını elde edebilecek seviye gelebilmek için önemli bir yetenektir. Rekabet zekâsı oluşturabilmek için öğrenmeye bağlılığın ve açık görüşlülügüun olduğu ve ortak bir vizyonun paylaşıldığı öğrenen örgüt yapılarının işletmelerde uygulanması örgüt yöneticilerine önerilmektedir.

Son olarak dönüştürücü liderliğin rekabet zekasına olumlu etkisinde öğrenmeye bağlllık, paylaşılan vizyon ve açık görüşlülük teker teker tam aracı rol oynamıştır. Daha açık bir ifadeyle örgütsel öğrenme alt boyutları devreye girince dönüştürücü liderlik anlamsız hale gelmiştir. Yukarıda belirtildiği gibi bilgi ve istihbarat edinme ve bunu örgütün rekabet üstünlügü için kullanma becerisi için dönüştürücü liderlik biçimi oldukça önemlidir. Ancak bu durum öğrenen örgüt yapısının oluşturulduğu örgütlerde etkili çalışmaktadır. Bu nedenle otel yöneticilerine kararlara katılımın ve paylaşılan ortak vizyonun olduğu, risk alınabilen, takım halinde hareket edilebilen, bilgi paylaşımının yüksek olduğu ve açık görüşlü bir yapıya sahip örgüt kültürü oluşturmaları önerilmektedir. Sonuçlar göstermektedir ki öğrenme yönlü bir kültürün içerisinde rekabet zekâsına yönelik dönüştürücü liderliğin etkinliği artacaktır.

\section{KAYNAKÇA}

Akbaba, A. İ. (2019). Endüstri 4.0 ve 3 Boyutlu Yazıcılar. (1. Basım), Ankara: İmaj Yayınevi.

AlOwais, T. M. (2019). Influence of Transformational Leadership Style on Global Competitive Advantage through Innovation and Knowledge, Modern Applied Science, 13(1): 183-191.

Avolio, B. J. (1999). Full Leadership Development: Building the Vital Forces in Organizations. Thousand Oaks, CA: Sage Publications.

Avolio, B. J., Bass, B. M. and Jung, D. I. (1999). Re-Examining the Components of Transformational and Transactional Leadership Using Multifactor Leadership Questionnaire, Journal of Occupational and Organizational Psychology, 72: 441-462.

Baker, W. E. and Sinkula, J. M. (2002). Market Orientation, Learning Orientation and Product Innovation: Delving into The Organizations Black Box, Journal of Market Focused Management, 5: 5-23.

Baker, W. E. and Sinkula, J. M. (1999). The Synergistic Effect of Market Orientation and Learning Orientation on Organizational Performance, Journal of the Academy of Marketing Science, 27(4): 411427.

Bass, B. M., Avolio, B. J., Jung, D. I. and Berson, Y. (2003). Predicting Unit Performance by Assessing Transformational and Transactional Leadership, Journal of Applied Psychology, 88(2): 207-218.

Bass, B. M. (1990). Bass \& Stogdill's Handbook of Leadership. New York: The Free Pres. 
Bayraktaroglu, S. and Kutanis, R. (2003). Transforming Hotels into Learning Organisations: A New Strategy for Going Global, Tourism Management, 24(2): 149-154.

Bergeron, P. and Hiller C.A. (2002). Competitive Intelligence, asis\&t, 36(1): 2-628. https://asistdl.onlinelibrary.wiley.com/toc/15508382/2002/36/1 [Erişim Tarihi: 15.01.2020).

Bolt, F. J. (2000). Geleceğin Lideri. İstanbul: Form Yayınları.

Burns, J. M. (1978). Leadership, Harper \& Row. New York: The Free Press.

Carless, S. A., Wearing, A. J. and Mann, L. (2000). A Short Measure of Transformational Leadership, Journal of Business and Psychology, 14 (3): 389-405.

Chen, X. (2012). Impact of Business Intelligence and IT Infrastructure Flexibility on Competitive Advantage: An Organizational Agility Perspective, Doctoral Thesis, University of Nebraska, Lincoln.

Collins, J. (2004). İyiden Mükemmel Şirkete. (Çeviren, Cinemre, L.) İstanbul: Boyner Yayınları.

Cook, M. and Cook, C. W. (2000). Competitive Intelligence: Create an Intelligent Organization and Compete to Win. Londra: Kogan Page.

Day, G. S. and Wensley, R. (1988). Assessing Advantage: A Framework for Diagnosing Competitive Superiority, Journal of Marketing, 52(2): 1-20.

Deshpandé, R., Farley, J. U., and Webster, F. E. (1993). Corporate Culture, Customer Orientation, and Innovativeness in Japanese Firms: A Quadrad Analysis, International Journal of Research in Marketing, 57(1): 23-37.

Dickson, P. R. (1992). Toward A General Theory of Competitive Rationality, Journal of Marketing, 56(1): 69-83.

Dishman, P. L. and Calof, J. L. (2008). Competitive Intelligence: A Multiphasic Precedent to Marketing Strategy, European Journal of Marketing, 42(7/8): 766-785.

Du Toit, A. S. (2016). Using Environmental Scanning to Collect Strategic Information: A South African Survey, International Journal of Information Management, 36(1): 16-24.

Dugal, M. S. (1996). Integrating Competitive Intelligence in Organizations, Doctoral Thesis, University of Pittsburgh, Pittsburgh.

Fiol, C. M. and Lyles, M. A. (1985). Organizational Learning, Academy of Management Review, 10(4): 803-813.

Garvin, D. A. (1999). Öğrenen Bir Örgüt Yaratmak Bilgi Yönetimi. (Çeviren, Gündüz, B.) İstanbul: Mess Yayınları.

Grooms, T. F. (2001). Marketing Intelligence: Executive Management Pereceptions of Value, Doctoral Thesis, Brunel University, London.

Guimaraes, T. (2000). The Impact of Competitive Intelligence and IS Support in Changing Small Business Organizations, Logistics Information Management, 13(3): 117125.

Güler, M. Ş. (2019). Kişilik Özellikleri Psikolojik Beceri ve Algılanan Stres Arasındaki İlişkinin Incelenmesi. (1. Basım), Ankara: Gece Akademi.

Hall, C. and Bensoussan, B. E. (2007). Staying ahead of The Competition: How Firms Really Manage Their Competitive Intelligence and Knowledge; Evidence from A Decade of Rapid Change. Singapur: World Scientific Publishing.

Hamel, G. and Prahalad, C. K. (1996). Competing for the Future. Boston: Harvard Business Press. 
Hasebrook, J. (2002). Lernen $f_{3} r$ Die Lernende Organisation. Frankfurt: Educational Financal Portal Der Bankakademie e.V.

Hesford, J. W. (1998). Determinants of The Use of Competitors' Accounting Information by Competitive Intelligence Professionals, Doctoral Thesis, University of Southern California, California.

Kim, D. H. (1993). The Link between Individual and Organizational Learning, Sloan Management Review, 35(1): 37-50.

Koçel, T. (2011). İşletme Yöneticiliği. (13. Basım), İstanbul: Beta Basım.

Köseoglu, M. A., Ross, G. and Okumus, F. (2016). Competitive Intelligence Practices in Hotels. International Journal of Hospitality Management, 53: 161-172.

Kula, M.E. (2019). Stratejik Düşünce ve Rekabet Zekâsı Otomotiv ve İletişim Endüstrilerinde Karşılaştırmalı Bir Araştırma, Yayınlanmamış Doktora Tezi, Atatürk Üniversitesi, Erzurum.

Li, T. and Calantone, R. J. (1998). The Impact of Market Knowledge Competence on New Product Advantage: Conceptualization and Empirical Examination, Journal of Marketing, 62(4): 13-29.

Lowe, K. B., Galen, K. K. and Sivasubramaniam, N. (1996). Effectiveness Correlates of Transformational and Transactional Leadership: A Meta-Analytic Rewiew of The MLQ Literatüre, Leadership Quaterly, 7(3): 385-425.

Lundberg, C. C. (1995). Learning in and by Organizations: Three Conceptual Issues, International Journal of Organizational Analysis, 3(1): 10-23.

Mcgill, M. E., Slocum, J. W. and Lei, D. (1992). Management Practices in Learning Organizations, Organizational Dynamics, 21(1): 5-17.

Meydan, C. H. ve Şeşen, H. (2011). Yapısal Eşitlik Modellemesi: AMOS Uygulamaları, Ankara: Detay Yayincilik.

Miller, J. (2000). Millennium Intelligence: Understanding and Conducting Competitive Intelligence in The Digital Age. New Jersey: CyberAge Books.

Morgan, R. E. and Turnell, C. R. (2003). Market-Based Organizational Learning and Market Performance Gains, British Journal of Management, 14: 255-274.

Murphy, C. (2005). Competitive Intelligence: Gathering, Analysing and Putting It to Work. Gower House: Gower Publishing Limited.

Naktiyok, S. ve İşcan, Ö. F. (2019). Örgütsel Desteğin Örgütsel Bağlllık Üzerine Etkisinde Örgütsel Güven Algısının Aracı Rolü, İsletme Araştırmaları Dergisi, 11(2): 1029-1043.

Porter, M. E. (2000). Rekabet Stratejisi: Sektör ve Rakip Analizi Teknikleri. (Çeviren, Ulubilgen, G.), İstanbul: Sistem Yayıncilık.

Prescott, J. E. (1999). The Evolution of Competitive Intelligence. International Review of Strategic Management, 6: 37-52.

Probst, G. J. B. and Büchel, B. S. T. (1997). Organizational Learning: The Competitive Advantage of The Future. London: Prentice Hall.

Qiu, T. (2008). Scanning for Competitive Intelligence: A Managerial Perspective, European Journal of Marketing, 42(7/8): 814-835.

Riaz, T., Akram, M. U. and Ijaz, H. (2011). Impact of Transformational Leadership Style on Affective Employees' Commitment: An Empirical Study of Banking Sector in Islamabad (Pakistan), The Journal of Commerce, 3(1): 43-51. 
Romme, G. and Dillon, R. (1997). Mapping the Landcape of Organizational Learning, European Management Journal, 15(1): 68-78.

Saayman, A., Pienaar, J., De Pelsmacker, P., Viviers, W., Cuyvers, L., Muller, M. L. and Jegers, M. (2008). Competitive Intelligence: Construct Exploration, Validation and Equivalence. In Aslib Proceedings, Emerald Group Publishing Limited, 60(4): 383-411.

Salmon, R. and De Linares, Y. (1999). Competitive Intelligence: Scanning the Global Environment. Calgary: Economica Limited.

Salner, M. (1999). Preparing for The Learning Organization, Journal of Management Education, 23(5): 489-508.

Sawka, K. A., Francis, D. B. and Herring, J. P. (1996). Evaluating Business Intelligence Systems: How Does Your Company Rate?, Competitive Intelligence Review, 6(4): 22-25.

Scandura, T. A. and Ethlyn, A. W. (2004). Mentoring and Transformational Leadership: The Role of Supervisory Career Mentoring, Journal of Vocational Behavior, 65: 448-468.

Schein, E. H. (1992). Organizational Culture and Leadership. San Francisco: JosseyBoss.

Schermerhorn, J. (1993). Management for Productivity. New York: John Wiley and Sons.

Senge, P. M. (2006). Beşinci Disiplin: Öğrenen Organizasyon Düşünüşü ve Uygulaması. (Çeviren, İldeniz A. ve Doğukan A.), İstanbul: Yapı Kredi Yayınları.

Senge, P. M. (2000). Beşinci Disiplin: Öğrenen Organizasyon Düşünüşü ve Uygulaması. (Çeviren, İldeniz A. ve Doğukan A.), İstanbul: Yapı Kredi Yayınları.

Seymen, O. A. ve Bolat, T. (2002). Örgütsel Öğrenme, Bursa: Ezgi Kitabevi.

Sinkula, J. M. (1994). Market Information Processing and Organizational Learning, Journal of Marketing, 58(1): 35-45.

Slocum, J. W., Mcgill, M. and Lei, D. T. (1994). The New Learning Strategy: Anytime, Anything, Anywhere, Organizational Dynamics, 23(2): 33-47.

Taşgın, A. ve Korucuk, M. (2019). Meslek Yüksekokulu Öğrencilerinin Çoklu Zekâ Alanlarının İncelenmesi, Kuramsal Ĕ̆itimbilim Dergisi, 12(2): 550-575.

Teo, T. S. and Choo, W. Y. (2001). Assessing the Impact of Using The Internet for Competitive Intelligence, Information \& Management, 39(1): 67-83.

Tims, M., Bakker, A.B. and Xanthopoulou, D. (2011). Do Transformational Leaders Enhance Their Followers' Daily Work Engagement?, The Leadership Quarterly, 22(1): 121-131.

Timuroğlu, M. K., Naktiyok, A. and Kula, M. E. (2016). Strategic Thought and Learning Orientation, South Asian Journal of Management, 23(4): 7-30.

Tse, H. M. and Lam, W. (2008). Transformational Leadership and Turnover: The Role of LMX and Organizational Commitment, Academy of Management, 1: 1- 6.

Walumba, F. O., Bani, O., Pengy, W. and Lawler, J. J. (2005). Transformational Leadership, Organizational Commitment and Job Satisfaction: A Comparative Study of Kenyan and U.S. Financial Firms, Human Resource Development Quarterly, 16(2): 235-256

Wright, S., Bisson, C. and Duffy, A. (2013). Competitive Intelligence and Information Technology Adoption of SMEs in Turkey: Diagnosing Current Performance and Identifying Barriers, Journal of Intelligence Studies in Business, 3(2): 5-29. 
Yıldırım, F. ve Karabey, C. N. (2016). Örgüt Kültürünün Yeniliğe Etkisinde Personel Güçlendirmenin Biçimlendirici Rolü, Gazi Üniversitesi İktisadi ve İdari Bilimler Fakültesi Dergisi, 18(2): 426-453. 